\title{
Preliminary Study on Private College English Teaching Satisfaction \\ Calculation Model
}

\author{
a Jian Yang, ${ }^{b}$ Li-tao Jiao
}

Qingdao Huanghai University,

No.3111, Linghai Road, Huangdao District, Qingdao City, Shandong Province, China ayangjian8482@163.com

bJiaolitao_11@163.com

Keywords: Private colleges; English teaching satisfaction; Calculation Model

\begin{abstract}
Through the college English teaching satisfaction survey of private colleges, this paper uses comprehensive fuzzy evaluation method and calculation model to analyze the factors affecting student satisfaction and put forward suggestions in improving English teaching satisfaction in private colleges.
\end{abstract}

\section{Introduction}

At present, domestic research model on higher education satisfaction mostly comes from the study of customer satisfaction model for reference, in the late $1970 \mathrm{~s}$ abroad countries began discussing the effectiveness of students evaluation reflecting teaching level .

Foreign research on student satisfaction model is generally basic research, not for a region or a certain quality is studied; and it gives priority to individual behavior survey, pays more attention to the relationship between the individual needs and behavior with student satisfaction. For satisfaction research, evaluation method is generally not a single method. When it does investigation, it also records behavior observation to obtain the objective data to support $^{[1]}$.

From the retrieval literature, we found that since 2005, our country started on teaching satisfaction survey, but less study on satisfaction model. The degree of satisfaction index has not formed systemic model, and the evaluation index is not systematic. According to the analysis of status quo of satisfaction, further research may be to build the evaluation index system, looking for effective assessment tools, deep processing research data, etc ${ }^{[2]}$.

\section{Questionnaire design}

Questionnaire is divided into filling explanation, questionnaire, answers, and the conclusion. From teaching form, teaching environment, teaching content, teaching method, teachers level, teaching effect six aspects, this paper uses Likert scale positive statements to design, divides into "very satisfied", "satisfied", "general", "dissatisfied", "very dissatisfied" five grades, according to the 5, 4, 3, 2, 1 for scoring, make partial product and evolution for statistical analysis. In addition, the students can fill out the most dissatisfactory aspects of college English teaching and education suggestions. ${ }^{[3]}$ 


\section{Calculation Model design}

\section{Individual satisfaction model}

Assume that $\eta_{i}$ is satisfaction index, $\beta_{m}$ is sample satisfaction survey average score, $\beta_{i}$ is individual satisfaction survey scores, then:

$\eta_{t}=\beta_{i} / \beta_{m}$

if $\eta_{i} \geq 1$, then record " the student is satisfied", satisfaction is $100 \%$;

if $1>\eta_{i} \geq 0.8$, then record " the student is relatively satisfied", satisfaction is $\eta_{i} * 100 \%$

if $0.8>\eta_{i} \geq 0.6$, then record " the student is not satisfied", satisfaction is $\eta_{i} * 100 \%$; if $\eta_{i}<0.6$, then record " the student is very dissatisfied", satisfaction is $\eta_{i} * 100 \%$.

\section{Community satisfaction model}

We assume that $\chi_{i}$ is community satisfaction index, then $\chi_{i}=\sqrt[n]{\prod_{j=1}^{n} \eta_{i, j}} \quad(n$ is the community sample number $)$

if $\chi_{i} \geq 1$, then record " the community is satisfied", satisfaction is $100 \%$;

if $1>\chi_{i} \geq 0.8$, then record " the community is relatively satisfied", satisfaction is $\chi_{i} * 100 \%$

if $0.8>\chi_{i} \geq 0.6$, then record " the community is not satisfied", satisfaction is $\chi_{i} * 100 \%$

if $\chi_{i}<0.6$, then record " the community is very dissatisfied", satisfaction is $\chi_{i} * 100 \%$.

We can use questionnaire, edit computer programs, and then directly obtain satisfaction condition of the teacher or community.

\section{Survey results and analysis}

A random sample questionnaire was conducted among 100 students, the results of the survey is as follows (See Table 1): 
Table 1 Questionnaire analysis table of private college English teaching

\begin{tabular}{|c|c|c|c|c|}
\hline Number & Content & $\begin{array}{c}\text { Comprehensive } \\
\text { score }\end{array}$ & Rank & $\begin{array}{c}\text { Comprehensive } \\
\text { evaluation }\end{array}$ \\
\hline 1 & teaching form & 4.12 & 2 & very satisfied \\
\hline 2 & teaching environment & 3.98 & 3 & satisfied \\
\hline 3 & teaching content & 4.33 & 1 & very satisfied \\
\hline 4 & teaching method & 3.72 & 4 & satisfied \\
\hline 5 & teachers level & 3.28 & 6 & general \\
\hline 6 & teaching effect & 3.44 & 5 & general \\
\hline
\end{tabular}

From the survey results and according to comprehensive fuzzy evaluation method, students are relatively satisfied with college English teaching in the teaching form, teaching environment, teaching content and teaching method, the teaching level and teaching effect is not very recognized. According to the students' dissatisfied aspects and suggestion, through interviews with individual students, the dissatisfied cause analysis is as follows:

First, the teacher's teaching method and method is relatively single. Most of the English class teaching by cramming education and chalk blackboard teaching method.

Second, students have less time for English learning, learning, planning is not strong and low initiative. Currently private colleges did not attach enough importance to English teaching, students' foreign language learning time can't guarantee, at the same time the curriculum and teaching plan leads to lower learning plan and initiative.

Third, the low teachers level and teaching effect is not ideal. Currently private college English teachers' level is uneven. Given priority to pure knowledge and scores, and lack of heuristic teaching guide.

\section{Countermeasures}

\section{Take efforts to improve supporting facilities level of college English teaching reform}

It needs to build based on the network and computer system of college English teaching system, from teaching material construction, teaching facilities, learning environment, teaching management, etc. First of all, we must strengthen the construction of teaching facilities and learning environment, increase investment in hardware construction funds, and establish network and multimedia autonomous learning classroom, then select English network teaching materials specified by national ministry of education of college to provide abundant resources for English learning.

\section{Transform teachers'role and update teaching idea}

Teachers must transform their role from single knowledge imparter to the application of language instructor, leaders, and evaluators of studying quality. At the same time, they mainly deal with the relationship between knowledge and ability, as well as teaching and learning. The former must set up the idea which learning is the foundation of knowledge, cultivating 
ability is the key and improving students' comprehensive quality is the purpose; the latter must change the traditional teaching mode, change the focus of college English teaching to cultivate the language application ability. It should also regularly held seminars, symposia, etc and college English teachers should be encouraged to research teaching theory to improve the teachers level.

\section{Reform classroom teaching forms to improve students' learning initiative}

On the teaching forms and methods, we should do more communication and multimedia teaching; make full use of language LABS and Internet. Adapt heuristic, discussion-based method of teaching, organize class activities effectively, and fully mobilize the initiative of students learning. English teaching should use multimedia and network technology, make the text, images, sound, animation, and other media organically unifies together to create a harmonious relaxed environment for language learning.

\section{Attach great importance to second classroom construction and strengthen practice teaching}

Establish foreign language center, students will be organized to carry out a variety of colorful and distinctive traits of the second classroom activities, such as English corner, English speech contest, English drama performance to mobilize the enthusiasm of students, effectively excavate the potential of students and improve the students' language using ability.

\section{References}

[1] Qian Zhang. Higher Education Quality Evaluation and Student Satisfaction [J], China Higher Education Research, 2009, (11).

[2] Ying-bao Huo. Customer Satisfaction Evaluation and Application Research [M] Dongnan University Press, 2010,(04).

[3] Fu-li Sui. Some Thinking and Countermeasures Research of Student Satisfaction Evaluation in Higher School Class Teaching[J].Science and Education Latitude, 2009, (10). 